\title{
Potential Pathway of Nitrous Oxide Formation in Plants
}

\section{OPEN ACCESS}

Edited by:

Juan B. Barroso,

University of Jaén, Spain

Reviewed by:

Maria J. Delgado,

Estación Experimental de Zaidín

(CSIC), Spain

Francesco Di Gioia,

Pennsylvania State University (PSU),

United States

*Correspondence:

Arbindra Timilsina arbintms@sjziam.ac.cn

Chunsheng Hu

cshu@sjziam.ac.cn

Specialty section:

This article was submitted to

Plant Physiology,

a section of the journal

Frontiers in Plant Science

Received: 08 April 2020

Accepted: 20 July 2020

Published: 31 July 2020

Citation:

Timilsina A, Zhang C, Pandey B, Bizimana F, Dong W and Hu C (2020)

Potential Pathway of Nitrous Oxide

Formation in Plants.

Front. Plant Sci. 11:1177.

doi: 10.3389/fpls.2020.01177

\section{Arbindra Timilsina ${ }^{1,2 *}$, Chuang Zhang ${ }^{1,2}$, Bikram Pandey ${ }^{2,3}$, Fiston Bizimana ${ }^{1,2}$, Wenxu Dong ${ }^{1}$ and Chunsheng $\mathrm{Hu}^{1,2^{*}}$}

\begin{abstract}
${ }^{1}$ Key Laboratory of Agricultural Water Resources, Hebei Key Laboratory of Soil Ecology, Center for Agricultural Resources Research, Institute of Genetics and Developmental Biology, Chinese Academy of Sciences, Shijiazhuang, China, 2 University of Chinese Academy of Sciences, Beijing, China, ${ }^{3}$ Key Laboratory of Mountain Ecological Restoration and Bio-resource Utilization and Ecological Restoration Biodiversity Conservation Key Laboratory of Sichuan Province, Chengdu Institute of Biology, Chinese Academy of Sciences, Chengdu, China
\end{abstract}

Plants can produce and emit nitrous oxide $\left(\mathrm{N}_{2} \mathrm{O}\right)$, a potent greenhouse gas, into the atmosphere, and several field-based studies have concluded that this gas is emitted at substantial amounts. However, the exact mechanisms of $\mathrm{N}_{2} \mathrm{O}$ production in plant cells are unknown. Several studies have hypothesised that plants might act as a medium to transport $\mathrm{N}_{2} \mathrm{O}$ produced by soil-inhabiting microorganisms. Contrarily, aseptically grown plants and axenic algal cells supplied with nitrate $\left(\mathrm{NO}_{3}\right)$ are reported to emit $\mathrm{N}_{2} \mathrm{O}$, indicating that it is produced inside plant cells by some unknown physiological phenomena. In this study, the possible sites, mechanisms, and enzymes involved in $\mathrm{N}_{2} \mathrm{O}$ production in plant cells are discussed. Based on the experimental evidence from various studies, we determined that $\mathrm{N}_{2} \mathrm{O}$ can be produced from nitric oxide ( $\mathrm{NO}$ ) in the mitochondria of plants. $\mathrm{NO}$, a signaling molecule, is produced through oxidative and reductive pathways in eukaryotic cells. During hypoxia and anoxia, $\mathrm{NO}_{3}$ in the cytosol is metabolised to produce nitrite $\left(\mathrm{NO}_{2}\right)$, which is reduced to form $\mathrm{NO}$ via the reductive pathway in the mitochondria. Under low oxygen condition, $\mathrm{NO}$ formed in the mitochondria is further reduced to $\mathrm{N}_{2} \mathrm{O}$ by the reduced form of cytochrome c oxidase (CcO). This pathway is active only when cells experience hypoxia or anoxia, and it may be involved in $\mathrm{N}_{2} \mathrm{O}$ formation in plants and soil-dwelling animals, as reported previously by several studies. $\mathrm{NO}$ can be toxic at a high concentration. Therefore, the reduction of $\mathrm{NO}$ to $\mathrm{N}_{2} \mathrm{O}$ in the mitochondria might protect the integrity of the mitochondria, and thus, protect the cell from the toxicity of $\mathrm{NO}$ accumulation under hypoxia and anoxia. $\mathrm{As} \mathrm{NO}_{3}$ is a major source of nitrogen for plants and all plants may experience hypoxic and anoxic conditions owing to soil environmental factors, a significant global biogenic source of $\mathrm{N}_{2} \mathrm{O}$ may be its formation in plants via the proposed pathway.

Keywords: anoxia, hypoxia, nitrate, nitrite, nitric oxide, nitrous oxide, mitochondrion 


\section{INTRODUCTION}

Nitrous oxide $\left(\mathrm{N}_{2} \mathrm{O}\right)$ is a potent greenhouse gas, and its potential to increase global warming is approximately 300 -fold higher than $\mathrm{CO}_{2}$ (Tian et al., 2018). Globally, the primary sources that release $\mathrm{N}_{2} \mathrm{O}$ into the atmosphere are soil, ocean, manure application, industries, and biomass burning (Thomson et al., 2012). The nitrification and denitrification processes, mainly mediated by certain groups of soil micro-organisms (Hu et al., 2015), account for more than two-thirds of its emission into the atmosphere (Thomson et al., 2012). These processes are considerably increased by human activities, leading to an increase in the production of $\mathrm{N}_{2} \mathrm{O}$ in the soil, and thus, its concentration in the atmosphere. Increased level of $\mathrm{N}_{2} \mathrm{O}$ in the atmosphere has significantly contributed to global warming (Tian et al., 2018); therefore, understanding the pathways of $\mathrm{N}_{2} \mathrm{O}$ formation in various sources is essential for mitigating these effects.

Key pathways involved in $\mathrm{N}_{2} \mathrm{O}$ production in microbes include nitrification, nitrifier denitrification, nitrificationcoupled denitrification, and denitrification (Baggs, 2011; Hu et al., 2015; Tian et al., 2018). However, there seems to be a gap between source estimation and the global $\mathrm{N}_{2} \mathrm{O}$ budget, leading to a high level of uncertainty in the budget estimations (Davidson and Kanter, 2014). This gap may be because not all sources of $\mathrm{N}_{2} \mathrm{O}$ to the atmosphere are accounted for (Syakila and Kroeze, 2011). Therefore, it is necessary to understand all sources of $\mathrm{N}_{2} \mathrm{O}$ and underlying mechanisms to elucidate its global budget. The production of $\mathrm{N}_{2} \mathrm{O}$ in axenic microalgae (Weathers, 1984; Weathers and Niedzielski, 1986; Guieysse et al., 2013; Plouviez et al., 2017) and ascetically grown plants (Goshima et al., 1999; Hakata et al., 2003) indicates that it could be produced by higher organisms and that the processes might be different from those in micro-organisms. Algae and plants are not included as sources of $\mathrm{N}_{2} \mathrm{O}$ (Syakila and Kroeze, 2011; Lenhart et al., 2019; Plouviez et al., 2019), but they might be the missing sources of $\mathrm{N}_{2} \mathrm{O}$, causing high uncertainties in the global budget.

The roles of plants in $\mathrm{N}_{2} \mathrm{O}$ emission to the atmosphere are diverse. Plants can not only modify soil characteristics and subsequently influence $\mathrm{N}_{2} \mathrm{O}$ production in the soil (Gao et al., 2019) but also produce it in significant amounts and release it to the atmosphere (Lenhart et al., 2019). Thus, understanding the pathway of $\mathrm{N}_{2} \mathrm{O}$ formation and the contribution of plants to total emission is essential to accurately estimate the global $\mathrm{N}_{2} \mathrm{O}$ budget. Several field-based studies have hypothesised that $\mathrm{N}_{2} \mathrm{O}$ emitted by plants is produced in soil by microorganisms (Chang et al., 1998; Rusch and Rennenberg, 1998; Machacova et al., 2013; Bowatte et al., 2014; Wen et al., 2017). In this theory, plants are considered just a medium to transport $\mathrm{N}_{2} \mathrm{O}$ produced by soil microorganisms; however, laboratory-based studies have provided clear evidence that plants produce and emit $\mathrm{N}_{2} \mathrm{O}$ although the underlying mechanisms are unknown (Goshima et al., 1999; Hakata et al., 2003; Lenhart et al., 2019). Therefore, $\mathrm{N}_{2} \mathrm{O}$ emitted by plants might originate from two sources, namely, the soil microorganisms and plants.

Studies, which have hypothesised that plant-emitted $\mathrm{N}_{2} \mathrm{O}$ is produced by soil microorganisms, have only measured the fluxes from plants and concluded that plant-emitted $\mathrm{N}_{2} \mathrm{O}$ might be produced by soil microorganisms. $\mathrm{N}_{2} \mathrm{O}$ produced in plant cells might also use the same pathway, that is, transpiration, to release it to the atmosphere. This raises the question whether measuring the fluxes alone provides substantial evidence to prove the hypothesis, because flux measurement methods can just estimate the emission of $\mathrm{N}_{2} \mathrm{O}$ and cannot distinguish the sources. More robust methods such as isotope studies would provide more insights to distinguish the sources of $\mathrm{N}_{2} \mathrm{O}$. For examples, injecting ${ }^{15} \mathrm{~N}-\mathrm{N}_{2} \mathrm{O}$ into the root zone and measuring the subsequent fluxes would elucidate whether plants are a medium for $\mathrm{N}_{2} \mathrm{O}$ transport or not. However, no study has injected ${ }^{15} \mathrm{~N}$-labeled $\mathrm{N}_{2} \mathrm{O}$ into the soil zone and measured the subsequent $\mathrm{N}_{2} \mathrm{O}$ emission from plants. Moreover, more powerful tools such as site preference (SP) measurement would provide insights to distinguish the sources of $\mathrm{N}_{2} \mathrm{O}$ emitted by plants under field conditions.

In the natural environment, if plant emitted $\mathrm{N} 2 \mathrm{O}$ constitute significant amount of both sources (soil micro-organisms and plant cells produced $\mathrm{N} 2 \mathrm{O}$ ), it will be highly challenging to distinguish the portion of the sources. A recent field experiment reported considerably lower $\mathrm{N}_{2} \mathrm{O}$ concentrations in soil water than in tree stems (Ward et al., 2019). Similarly, plants exposed to $\mathrm{NH}_{4}$ did not emit $\mathrm{N}_{2} \mathrm{O}$ despite the high rate of $\mathrm{N}_{2} \mathrm{O}$ production in the rhizosphere (Smart and Bloom, 2001), indicating that $\mathrm{N}_{2} \mathrm{O}$ emitted by plants might not be produced by soil microorganisms and that $\mathrm{N}_{2} \mathrm{O}$ emitted through transpiration might be a less significant process than $\mathrm{N}_{2} \mathrm{O}$ production in plants. Furthermore, the hypothesis that plants are just a conduit for soil microorganisms-produced $\mathrm{N}_{2} \mathrm{O}$ is not supported by a recent study of Lenhart et al. (2019). They provided new evidence that dual isotopocule fingerprints of $\mathrm{N}_{2} \mathrm{O}$ emitted by plants differed from that produced by all known microbial or chemical processes, indicating that plantemitted $\mathrm{N}_{2} \mathrm{O}$ is produced in plant cells.

Although plants are known to produce $\mathrm{N}_{2} \mathrm{O}$ and emit it to the atmosphere, the exact mechanisms of $\mathrm{N}_{2} \mathrm{O}$ production in plant cells are unknown (Goshima et al., 1999; Hakata et al., 2003; Lenhart et al., 2019). This might be the reason that most studies on $\mathrm{N}_{2} \mathrm{O}$ fluxes in plants (Chang et al., 1998; Rusch and Rennenberg, 1998; Machacova et al., 2013; Bowatte et al., 2014; Wen et al., 2017) have hypothesised that plant parts act as a conduit for soil-produced $\mathrm{N}_{2} \mathrm{O}$. Studies, which have claimed that plants could produce $\mathrm{N}_{2} \mathrm{O}$, have not elucidated a possible production pathway. Therefore, the main objective of this study was to review the possible pathway of $\mathrm{N}_{2} \mathrm{O}$ formation in plant cells.

\section{PATHWAY OF $\mathrm{N}_{2} \mathrm{O}$ FORMATION IN PLANT CELLS}

\section{Nitrate $\left(\mathrm{NO}_{3}\right)$ as a Precursor for $\mathrm{N}_{2} \mathrm{O}$ Formation in Plant Cells}

Nitrogen $(\mathrm{N})$ is an essential macronutrient influencing cell metabolism (O'Brien et al., 2016). Plants can use several forms 
of $\mathrm{N}$ from the soil; however, $\mathrm{NO}_{3}$ and ammonium $\left(\mathrm{NH}_{4}\right)$ are the major forms of inorganic $\mathrm{N}$ that are readily available for plant uptake (O'Brien et al., 2016; Hachiya and Sakakibara, 2017). $\mathrm{NO}_{3}$ is a major source of $\mathrm{N}$ for plants in agricultural and natural soils (von Wirén et al., 2000), due to its high soil concentration and diffusion coefficients, making it readily available to plant roots (Miller and Cramer, 2005). After absorption, $\mathrm{NO}_{3}$ is directly reduced in the root, transported to the leaf for reduction (Maathuis, 2009; Hachiya and Sakakibara, 2017), or stored in the vacuoles and remobilised when the external supply is limited (van der Leij, et al., 1998; Fan et al., 2007), making it an essential macronutrient in plant metabolism.

$\mathrm{NO}_{3}$ is a major source for $\mathrm{N}_{2} \mathrm{O}$ formation in both soil (Thomson et al., 2012) and plants (Goshima et al., 1999; Smart and Bloom, 2001; Hakata et al., 2003; Lenhart et al., 2015; Lenhart et al., 2019). Isotope labeling methods have demonstrated that plants as well as other eukaryotic organisms emit $\mathrm{N}_{2} \mathrm{O}$, only when supplied with $\mathrm{NO}_{3}$. For example, when ${ }^{15} \mathrm{~N}$-labeled $\mathrm{NO}_{3}$ was supplied as a source of $\mathrm{N}$ to various species of plants (Goshima et al., 1999; Smart and Bloom, 2001; Lenhart et al., 2019), lichens (Lenhart et al., 2015), and animals (Stief et al., 2009), ${ }^{15} \mathrm{~N}$-labeled $\mathrm{N}_{2} \mathrm{O}$ was emitted, but when the $\mathrm{N}$ source was ${ }^{15} \mathrm{~N}$-labeled $\mathrm{NH}_{4}$, there was no $\mathrm{N}_{2} \mathrm{O}$ emission. This evidence clearly shows that $\mathrm{NO}_{3}$ is the precursor of $\mathrm{N}_{2} \mathrm{O}$ in lichens, higher plants, and animals. Therefore, if plants were just a medium of transportation of soil-produced $\mathrm{N}_{2} \mathrm{O}$ as hypothesised by many studies (Chang et al., 1998; Rusch and Rennenberg, 1998; Machacova et al., 2013; Bowatte et al., 2014; Wen et al., 2017), aseptically grown plants would not have emitted $\mathrm{N}_{2} \mathrm{O}$ when supplied with $\mathrm{NO}_{3}$ (Goshima et al., 1999; Hakata et al., 2003). Similarly, if $\mathrm{N}_{2} \mathrm{O}$ emitted by plants is produced by microorganisms (nitrifying and denitrifying bacteria), $\mathrm{NH}_{4}$ supplementation should contribute to $\mathrm{N}_{2} \mathrm{O}$ emission from plants and aseptically grown plants should not emit $\mathrm{N}_{2} \mathrm{O}$. As $\mathrm{N}_{2} \mathrm{O}$ was not emitted when plants were supplied with $\mathrm{NH}_{4}$ and aseptically grown plants emitted $\mathrm{N}_{2} \mathrm{O}$ (Goshima et al., 1999; Hakata et al., 2003), we predicted that $\mathrm{NO}_{3}$ metabolism in a cell might play a role in $\mathrm{N}_{2} \mathrm{O}$ formation in plants. Moreover, the processes in the soil microbial communities and higher organisms maybe different, or the denitrification process may be common between microorganism and plants, as $\mathrm{NO}_{3}$ is the substrate for denitrification.

\section{Nitrite $\left(\mathrm{NO}_{2}\right)$ Derived From $\mathrm{NO}_{3}$ Reduction Is the Precursor of $\mathrm{N}_{2} \mathrm{O}$ in Plant Cells}

After the uptake of $\mathrm{NO}_{3}$ by plant roots, it is reduced to $\mathrm{NO}_{2}$ in plant cells by a cytosolic enzyme called nitrate reductase (NR) (Chamizo-Ampudia et al., 2017). However, in animals, $\mathrm{NO}_{3}$ from food is reduced by bacteria in the digestive tracks (Lundberg et al., 2008). Moreover, germ-free mice are reported to possess NR activity, and the activity is catalysed by xanthine oxidoreductase, which is significantly high in the gastrointestinal tissues, compared with other tissues (Jansson et al., 2008). Under normal conditions, $\mathrm{NO}_{3}$ absorbed by the roots is reduced to $\mathrm{NO}_{2}$ by the $\mathrm{NR}$, and then nitrite reductase (NiR) catalyses the reduction of $\mathrm{NO}_{2}$ to $\mathrm{NH}_{4}$, which is incorporated into amino acids (Oliveira and Sodek, 2013; Plouviez et al., 2017). However, under hypoxic and anoxic conditions, root $\mathrm{NO}_{3}$ uptake increases with the activation level of NR (Botrel and Kaiser, 1997; Rockel et al., 2002; Morard et al., 2004; Horchani et al., 2010). Furthermore, $\mathrm{NO}_{2}$ accumulates in the cytoplasm of cells (Allègre et al., 2004; Morard et al., 2004), as both hypoxia and anoxia suppress the reduction of $\mathrm{NO}_{2}$ to $\mathrm{NH}_{4}$ (Botrel and Kaiser, 1997). A ${ }^{15} \mathrm{~N}$ isotope labeling study has showed that ${ }^{15} \mathrm{~N}-\mathrm{NO}_{2}$ assimilation into amino acids is sharply reduced under hypoxic conditions (Oliveira and Sodek, 2013). The accumulated $\mathrm{NO}_{2}$ in the cytoplasm enters the mitochondria with the help of proteins in the chloroplast (Sugiura et al., 2007; Gupta and Igamberdiev, 2011). Moreover, mitochondrial inner membrane anion channels may import $\mathrm{NO}_{2}$ to the mitochondria (Gupta and Igamberdiev, 2011).

Not only $\mathrm{NO}_{3}$, but also $\mathrm{NO}_{2}$ is widely reported to be a precursor of $\mathrm{N}_{2} \mathrm{O}$ in eukaryotic organisms. Using ${ }^{15} \mathrm{~N}$ isotope labeling method, it has been demonstrated that $\mathrm{NO}_{2}$ is another precursor of $\mathrm{N}_{2} \mathrm{O}$ formation in plants and algal cells. For example, when ${ }^{15} \mathrm{~N}$-labeled $\mathrm{NO}_{2}$ was supplied to aseptically grown tobacco plants (Goshima et al., 1999; Hakata et al., 2003) and algal systems (Weathers, 1984), they emitted ${ }^{15} \mathrm{~N}$ $\mathrm{N}_{2} \mathrm{O}$. Furthermore, axenic algae supplied with $\mathrm{NO}_{2}$ produced $\mathrm{N}_{2} \mathrm{O}$ (Guieysse et al., 2013; Plouviez et al., 2017). The enzyme NR has been proved to play a role in $\mathrm{N}_{2} \mathrm{O}$ production in plants. For example, when tobacco plants were supplied with $\mathrm{NO}_{3}$ and tungstate ( $\mathrm{NR}$ inhibitor), $\mathrm{N}_{2} \mathrm{O}$ production was inhibited in the plants (Goshima et al., 1999). As $\mathrm{NO}_{2}$ also contributes to $\mathrm{N}_{2} \mathrm{O}$ production in plants (Goshima et al., 1999; Hakata et al., 2003), $\mathrm{NR}$ might indirectly be involved in $\mathrm{N}_{2} \mathrm{O}$ formation by catalysing the reduction of $\mathrm{NO}_{3}$ to $\mathrm{NO}_{2}$. A similar role of $\mathrm{NR}$ has been observed in algae (Plouviez et al., 2017). However, NiR-deficient transgenic plants and algae have been reported to produce $\mathrm{N}_{2} \mathrm{O}$ when supplied with $\mathrm{NO}_{2}$ (Hakata et al., 2003; Plouviez et al., 2017), and this suggests that the pathway of $\mathrm{NO}_{2}$ reduction to $\mathrm{NH}_{4}$ is not involved in $\mathrm{N}_{2} \mathrm{O}$ production in plants and algal cells. Additionally, $\mathrm{NO}_{3}, \mathrm{NR}$, and $\mathrm{NO}_{2}$ are involved in $\mathrm{N}_{2} \mathrm{O}$ production in plants and algal cells, but $\mathrm{NiR}$ and $\mathrm{NH}_{4}$ are not involved in the $\mathrm{N}_{2} \mathrm{O}$ production pathway. This indicates that $\mathrm{NO}_{2}$ has to be transported to other cell organelles rather than plastid. Overall, the available evidence indicates that exogenous $\mathrm{NO}_{2}$ along with endogenous $\mathrm{NO}_{2}$ derived through $\mathrm{NO}_{3}$ reduction in the cytosol by $\mathrm{NR}$ plays a role in $\mathrm{N}_{2} \mathrm{O}$ formation in plant cells.

\section{Mitochondrial Reduction of Nitrite to NO}

We previously discussed $\mathrm{NO}_{3}$ reduction to $\mathrm{NO}_{2}$ in the cytosol. NO has several essential roles in plant and animal cells (Wendehenne et al., 2001), and the conversion mechanisms of $\mathrm{NO}_{2}$ to $\mathrm{NO}$ are well established in eukaryotic cells. In plants, NO can be produced in the chloroplast, peroxisomes, and mitochondria by either oxidative or reductive pathways (Roszer, 2012). The oxidative pathway is dependent on Larginine, polyamine, or hydroxylamine, whereas the reductive pathway is dependent on $\mathrm{NO}_{3}$ and $\mathrm{NO}_{2}$ (Benamar et al., 2008; Lundberg et al., 2008; Gupta et al., 2011; Gupta and Igamberdiev, 
2011; Astier et al., 2018). The oxidative pathway of NO formation is dominant when the oxygen supply to cells is sufficient, whereas the reductive path is dominant under hypoxic conditions. By shifting from the oxidative to reductive pathway, the cells maintain the level of $\mathrm{NO}$ along with the physiological and pathological oxygen and proton gradients (Lundberg et al., 2008). It may be essential to shift processes, as plants may experience hypoxia due to soil environmental conditions.

In plant cells, $\mathrm{NO}_{2}$ assimilation to $\mathrm{NH}_{4}$ by the $\mathrm{NiR}$ enzyme is a well-known pathway of $\mathrm{NO}_{2}$ metabolism. As $\mathrm{NO}_{2}$ addition can lead to $\mathrm{N}_{2} \mathrm{O}$ formation in plants (Goshima et al., 1999; Hakata et al., 2003) and NiR-deficient plants can produce $\mathrm{N}_{2} \mathrm{O}$ (Hakata et al., 2003), we suggest that $\mathrm{NO}_{2}$ is metabolised by another pathway in plants to produce $\mathrm{N}_{2} \mathrm{O}$. Although the mechanisms of $\mathrm{NO}_{2}$ transport to the mitochondria are not precise, it is evident that the mitochondria are a site of reduction of $\mathrm{NO}_{2}$ to $\mathrm{NO}$. For example, the mitochondria have been reported to reduce $\mathrm{NO}_{2}$ to $\mathrm{NO}$ under hypoxic and anoxic conditions in fungi (Kobayashi et al., 1996; Castello et al., 2006), algae (Tischner et al., 2004; Calatrava et al., 2017), plants (Gupta et al., 2005; Planchet et al., 2005; Benamar et al., 2008; Gupta and Kaiser, 2010), and animals (Ghafourifar and Richter, 1997; Giulivi et al., 1998; Kozlov et al., 1999; Castello et al., 2006; Ascenzi et al., 2014). However, the enzymes involved in the mitochondrial reduction of $\mathrm{NO}_{2}$ to $\mathrm{NO}$ are not clear. For example, mitochondria that lack $\mathrm{NiR}$ can reduce $\mathrm{NO}_{2}$ to $\mathrm{NO}$ in animals and plants (Gupta and Igamberdiev, 2011). Nitric oxide synthases (NOS) have been reported to be present in plant (Guo and Crawford, 2005) and animal mitochondria (Giulivi et al., 1998). However, the NOS activity in the mitochondria of plants is questioned (Moreau et al., 2008; Gupta and Kaiser, 2010). Tischner et al. (2004) identified an alternative oxidase (AOX) in the mitochondria as a catalyser of the reduction of $\mathrm{NO}_{2}$ to $\mathrm{NO}$ under anoxic conditions. The mitochondrial respiratory chain is responsible for $\mathrm{NO}$ production using $\mathrm{NO}_{2}$ as the substrate under low pH, hypoxic, or anoxic conditions (Castello et al., 2006). Mitochondrial and bacterial electron transport chains (ETCs) are involved in $\mathrm{NO}$ production from $\mathrm{NO}_{2}$ under hypoxic conditions than under normoxic conditions (Horchani et al., 2011). Under hypoxic conditions, $\mathrm{NO}_{2}$ is reduced to $\mathrm{NO}$ at complex III in the mitochondria of pea plants (Benamar et al., 2008). Ascenzi et al. (2014) reported cytochrome $\mathrm{c}$ in horse heart cells and bovine heart reduced $\mathrm{NO}_{2}$ to $\mathrm{NO}$, and the activity was high under anoxic and acidic conditions (Basu et al., 2008). The mitochondrial molybdopterin enzymes in the reduced form catalyse the reduction of $\mathrm{NO}_{2}$ to $\mathrm{NO}$, and the rate was increased when the $\mathrm{pH}$ was decreased from 7.5 to 6.5 (Jakobs et al., 2014; SparacinoWatkins et al., 2014; Maia and Moura, 2015; Bender and Schwarz, 2018). Furthermore, cytochrome reductase in tobacco plants can reduce $\mathrm{NO}_{2}$ to $\mathrm{NO}$ (Alber et al., 2017). Although at the molecular level, the reductive pathway for $\mathrm{NO}$ formation is well documented, at the field scale, the emission of NO is less documented. For instance, when plants were supplied with $\mathrm{NO}_{3}, \mathrm{NO}$ was emitted under anoxic conditions (Klepper, 1987; Rockel et al., 2002). The leaf $\mathrm{NO}_{2}$ level and $\mathrm{NO}$ emission under anoxic conditions were significantly higher than those under normoxic conditions (Rockel et al., 2002). These findings suggest that $\mathrm{NO}_{2}$ can be reduced to $\mathrm{NO}$ in the mitochondria; however, the involvement of various enzymes within the mitochondria raises the question whether these enzymes catalyse the reduction process simultaneously or they function differently under varied cell environment.

\section{NO Conversion to $\mathrm{N}_{2} \mathrm{O}$ in the Mitochondria}

$\mathrm{NO}$ is a signaling molecule in cells, and several studies have focused on its formation in the mitochondria. However, studies on the reduction of $\mathrm{NO}$ to $\mathrm{N}_{2} \mathrm{O}$ in the mitochondria are limited, although there is a strong indication that this process exists (Gupta and Igamberdiev, 2011). The inner membrane of the mitochondria has an enzyme called cytochrome $c$ oxidase $(\mathrm{CcO})$. The primary function of $\mathrm{CcO}$ is to reduce $\mathrm{O}_{2}$ to $\mathrm{H}_{2} \mathrm{O}$ (Collman et al., 2007; Blomberg and Ädelroth, 2018). Moreover, $\mathrm{CcO}$ has several other functions, such as the oxidisation of $\mathrm{NO}$ formed in the mitochondria to $\mathrm{NO}_{2}$ (Brudvig et al., 1980; Zhao et al., 1995; Pearce et al., 2002; Taylor and Moncada, 2010). Furthermore, the reduced form of $\mathrm{CcO}$ can catalyse the reduction of $\mathrm{NO}$ to $\mathrm{N}_{2} \mathrm{O}$ (Brudvig et al., 1980; Zhao et al., 1995). Thus, either oxidation or reduction of $\mathrm{NO}$ by $\mathrm{CcO}$ results in the metabolism of $\mathrm{NO}$ with safe end products. The similar properties of $\mathrm{O}_{2}$ and $\mathrm{NO}$ facilitate the binding of $\mathrm{NO}$ to $\mathrm{CcO}$, and this activity is pronounced under oxygen-limited conditions (Ghafourifar and Cadenas, 2005). The mitochondrial electron transport chain (ETC) in axenic algae (Chlamydomonas reinhardtii and Chlorella vulgaris) catalyses the reduction of $\mathrm{NO}$ to $\mathrm{N}_{2} \mathrm{O}$ (Guieysse et al., 2013; Plouviez et al., 2017; Plouviez et al., 2019). CcO has some rudimentary nitric oxide reductase activity, and therefore, when $\mathrm{NO}$ is the substrate instead of $\mathrm{O}_{2}$, two molecules of $\mathrm{NO}$ yield $\mathrm{N}_{2} \mathrm{O}$ and $\mathrm{H}_{2} \mathrm{O}$ (Brudvig et al., 1980; Zhao et al., 1995; Koivisto et al., 1997; Igamberdiev et al., 2010; Blomberg and Ädelroth, 2018; Poderoso et al., 2019). It has also been proven isotopically that $\mathrm{NO}$ is reduced to $\mathrm{N}_{2} \mathrm{O}$ by $\mathrm{CcO}$ in higher organisms (Brudvig et al., 1980). As mitochondrial $\mathrm{CcO}$ has evolved from denitrifying enzymes, under hypoxic conditions in cells, the mitochondrial $\mathrm{CcO}$ can still reduce $\mathrm{NO}$ to $\mathrm{N}_{2} \mathrm{O}$ (Saraste, 1994; Saraste and Castresana, 1994). Furthermore, another enzyme in the mitochondria, that is, quinone of the ETC catalyses NO reduction to $\mathrm{N}_{2} \mathrm{O}$ (Alegria et al., 2004; Igamberdiev and Hill, 2009; Sanchez-Cruz and Alegría, 2009). Therefore, mitochondria can be a potent site of $\mathrm{N}_{2} \mathrm{O}$ formation under oxygen-limited conditions, and it should be a focus of future research.

Similar to the observations in plants, macrofauna and earthworms are also found to emit $\mathrm{N}_{2} \mathrm{O}$ when supplied with $\mathrm{NO}_{3}$ and under $\mathrm{O}_{2}$-limited conditions (Horn et al., 2003; Stief et al., 2009). Earthworms do not produce $\mathrm{N}_{2} \mathrm{O}$ when supplied $\mathrm{NH}_{4}$ (Horn et al., 2003). Moreover, in other studies, listed in Table 1, when ${ }^{15} \mathrm{~N}$-labeled $\mathrm{NH}_{4}$ was used as a substrate, there was no $\mathrm{N}_{2} \mathrm{O}$ emission. This shows that $\mathrm{NO}_{3}$ metabolism at the cellular level produces $\mathrm{N}_{2} \mathrm{O}$ in both plants and animals. As described above, the ETC in (Figure 1) mitochondria can reduce $\mathrm{NO}$ to $\mathrm{N}_{2} \mathrm{O}$ under less oxic conditions, which suggests 
that $\mathrm{N}_{2} \mathrm{O}$ emitted by earthworms and macrofauna (Horn et al., 2003; Stief et al., 2009) might also be produced from hypoxic mitochondria. The gut of insects has a hypoxic environment (Johnson and Barbehenn, 2000), which may explain the higher level of $\mathrm{N}_{2} \mathrm{O}$ production in the gut (Stief et al., 2009). Moreover, axenic algae supplied with $\mathrm{NO}_{2}$ produced significantly higher levels of $\mathrm{N}_{2} \mathrm{O}$ under dark conditions than under light conditions (Guieysse et al., 2013; Plouviez et al., 2017). The low emission of $\mathrm{N}_{2} \mathrm{O}$ under light conditions may be due to the supply of photosynthetic $\mathrm{O}_{2}$ to the cells.

Based on experimental evidence gathered from various studies, we propose that the reductive pathway of NO formation in the mitochondria and further reduction of $\mathrm{NO}$ by the mitochondrial ETCs contributes to the formation of $\mathrm{N}_{2} \mathrm{O}$ (in eukaryotic cells, as presented in Figure 1). The process is catalysed by various enzymes, and it might be pronounced under hypoxic and anoxic conditions but not under normoxic conditions. The proposed pathway is further supported by the existence of a denitrifying pathway, and the associated enzymes and genes in Globobulimina species and the localisation of enzymes in the mitochondria (Woehle et al., 2018). As higher animals possess well developed respiratory and circulatory systems that transport $\mathrm{O}_{2}$, they may not experience hypoxia. However, plants lack such sophisticated systems to transport $\mathrm{O}_{2}$ (Voesenek et al., 2016), and therefore, may experience hypoxia and anoxia that favour $\mathrm{N}_{2} \mathrm{O}$ formation. Field studies have reported high $\mathrm{N}_{2} \mathrm{O}$ emission from plants under flooded conditions (Rusch and Rennenberg, 1998; Machacova et al., 2013), suggesting the role of hypoxia and anoxia in $\mathrm{N}_{2} \mathrm{O}$ formation in plants.

\section{SIGNIFICANCE OF $\mathrm{N}_{2} \mathrm{O}$ FORMATION VIA THE $\mathrm{NO}_{3}-\mathrm{NO}_{2}-\mathrm{NO}$ PATHWAY IN PLANTS}

$\mathrm{NO}_{3}$ is not only a major nutrient in plant cells but also a signaling molecule (Zhao et al., 2018). Several studies have reported that $\mathrm{NO}_{3}$ plays a role in hypoxia tolerance. For example, $\mathrm{NO}_{3}$ maintains the growth of plants under oxygen-limited conditions, and its absence disturbs plant growth (Horchani et al., 2010). Anoxia tolerance of tomato plant is enhanced by nitrate reduction (Allègre et al., 2004). Moreover, anoxia strongly induces NR activity and the induced NR

TABLE 1 | Compilation of the substrates, mediums and products that used labeled $\mathrm{N}$ sources and their subsequent measurements of $\mathrm{N}_{2} \mathrm{O}$ emissions.

\begin{tabular}{|c|c|c|c|c|}
\hline & Substrate & Medium & Product & Reference \\
\hline 1. & $\begin{array}{l}{ }^{15} \mathrm{~N} \text { labeled } \mathrm{NO}_{3} \\
{ }^{15} \mathrm{~N} \text { labeled } \mathrm{NH}_{4}\end{array}$ & Aseptically grown tobacco plants & $\begin{array}{l}{ }^{15} \mathrm{~N} \text { labeled } \mathrm{N}_{2} \mathrm{O} \\
\mathrm{No} \mathrm{N}_{2} \mathrm{O} \text { emission }\end{array}$ & Goshima et al. (1999) \\
\hline 2. & $\begin{array}{l}{ }^{15} \mathrm{~N} \text { labeled } \mathrm{NO}_{3} \\
{ }^{15} \mathrm{~N} \text { labeled } \mathrm{NH}_{4}\end{array}$ & Lichen & $\begin{array}{l}{ }^{15} \mathrm{~N} \text { labeled } \mathrm{N}_{2} \mathrm{O} \\
\mathrm{No} \mathrm{N}_{2} \mathrm{O} \text { emission }\end{array}$ & Lenhart et al. (2015) \\
\hline 3. & $\begin{array}{l}{ }^{15} \mathrm{~N} \text { labeled } \mathrm{NO}_{3} \\
{ }^{15} \mathrm{~N} \text { labeled } \mathrm{NH}_{4}\end{array}$ & Wheat plant & $\begin{array}{l}{ }^{15} \mathrm{~N} \text { labeled } \mathrm{N}_{2} \mathrm{O} \\
\mathrm{No} \mathrm{N}_{2} \mathrm{O} \text { emission }\end{array}$ & Smart and Bloom (2001) \\
\hline 4. & ${ }^{15} \mathrm{~N}$ labeled $\mathrm{NO}_{3}$ & Soybean plant & ${ }^{15} \mathrm{~N}$ labeled $\mathrm{NO}$ and $\mathrm{N}_{2} \mathrm{O}$ & Dean and Harper (1986) \\
\hline 5. & ${ }^{15} \mathrm{~N}$ labeled $\mathrm{NO}_{3}$ & Macro fauna & ${ }^{15} \mathrm{~N}$ labeled $\mathrm{N}_{2} \mathrm{O}$ & Stief et al. (2009) \\
\hline 6. & ${ }^{15} \mathrm{~N}$ labeled $\mathrm{NO}_{2}$ & Tobacco plant & ${ }^{15} \mathrm{~N}$ labeled $\mathrm{N}_{2} \mathrm{O}$ & Goshima et al. (1999) \\
\hline 7. & ${ }^{15} \mathrm{~N}$ labeled $\mathrm{NO}_{2}$ & Aseptically grown tobacco plant & ${ }^{15} \mathrm{~N}$ labeled $\mathrm{N}_{2} \mathrm{O}$ & Hakata et al. (2003) \\
\hline 8. & ${ }^{15} \mathrm{~N}$ labeled $\mathrm{NO}_{2}$ & Axenic algae & ${ }^{15} \mathrm{~N}$ labeled $\mathrm{N}_{2} \mathrm{O}$ & Weathers (1984) \\
\hline 9. & $\begin{array}{l}{ }^{15} \mathrm{~N} \text { labeled } \mathrm{NO} \\
{ }^{14} \mathrm{~N} \text { labeled } \mathrm{NO}\end{array}$ & $\begin{array}{l}\text { Reduced form of beef heart cytochrome } \\
\text { c oxidase }(\mathrm{CcO})\end{array}$ & $\begin{array}{l}{ }^{15} \mathrm{~N} \text { labeled } \mathrm{N}_{2} \mathrm{O} \\
{ }^{14} \mathrm{~N} \text { labeled } \mathrm{N}_{2} \mathrm{O}\end{array}$ & Brudvig et al. (1980) \\
\hline
\end{tabular}

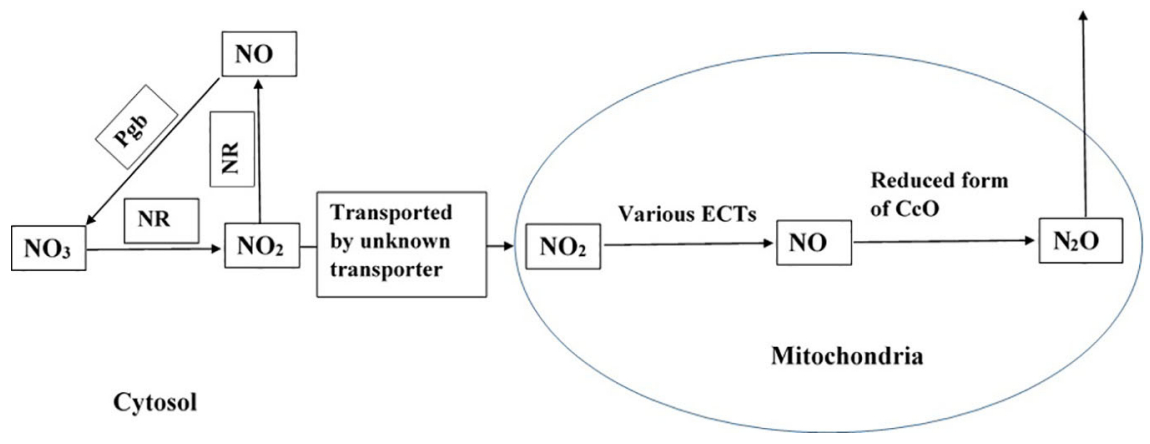

FIGURE 1 | Potential pathway of $\mathrm{N}_{2} \mathrm{O}$ formation in plant cells. NR represents nitrate reductase and Pgb represents phytoglobin (Brudvig et al., 1980 ; Zhao et al., 1995; Goshima et al., 1999; Gupta and Kaiser, 2010; Guieysse et al., 2013; Plouviez et al., 2017). The pathway is active in presence of $\mathrm{NO}_{3}$ and $\mathrm{NO}_{2}$, and when plants experience hypoxia and anoxia. 
activity prevents $\mathrm{pH}$ from dropping to life-threatening levels (Allègre et al., 2004). $\mathrm{NO}_{3}$ nutrition in plants decreases the total respiration rate and reactive oxygen species levels (Wany et al., 2019), but increases ATP production under hypoxic conditions (Stoimenova et al., 2007; Wany et al., 2019). Under oxygen-limited conditions, $\mathrm{NO}_{3}$ protects the ultrastructure of mitochondria (Vartapetian et al., 2003). The addition of $\mathrm{NO}_{3}$ to the root zone of plants released significantly less amount of ethanol compared with roots supplied with $\mathrm{NH}_{4}$ under hypoxic conditions (Oliveira et al., 2013). This suggests $\mathrm{NO}_{3}$ plays an important role to decrease alcoholic fermentative metabolism in plants during hypoxia (Oliveira et al., 2013). Overall, these findings suggest that $\mathrm{NO}_{3}$ and NR play an important role to maintain the integrity of plant cells under oxygen-limited conditions.

$\mathrm{NO}_{2}$ is also reported to play important roles under oxygenlimited conditions in plants. Benamar et al. (2008) found that $\mathrm{NO}_{2}$-dependent $\mathrm{NO}$ production in the mitochondria can regulate surrounding $\mathrm{O}_{2}$ level. Moreover, plant mitochondria can synthesise ATP under anaerobic conditions when supplied with $\mathrm{NO}_{2}$ (Stoimenova et al., 2007; Gupta et al., 2016). The supply of $\mathrm{NO}_{2}$ decreased lipid peroxidation and reactive oxygen species formation (Gupta et al., 2016). The absence of $\mathrm{NO}_{2}$ as a terminal acceptor for ETC during hypoxia leads to mitochondrial depolarisation (Gupta et al., 2016). $\mathrm{NO}_{2}$ supplemented roots released significantly less amount of fermentative ethanol during hypoxia than $\mathrm{NH}_{4}$-supplemented roots (Oliveira et al., 2012; Oliveira et al., 2013), suggesting the vital role of $\mathrm{NO}_{2}$ in plants to survive under oxygen-limited conditions.

NO helps plants to cope under several environmental stresses. For example, $\mathrm{NO}$ is essential for the homeostasis of $\mathrm{O}_{2}$ level in plants under oxygen-limited conditions (Gupta and Igamberdiev, 2011). NO production in the mitochondria has several implications in plants as illustrated in Figure 2. For example, NO can break seed dormancy and stimulate seed germination in plants (Beligni and Lamattina, 2000; Bethke et al., 2004). Similarly, under hypoxic stress, NO is vital for the formation of aerenchyma in the roots (Wany et al., 2017). NO production in the mitochondria under low-oxygen conditions can help in ATP synthesis, preventing excessive depletion of energy (Stoimenova et al., 2007). $\mathrm{NO}_{3}-\mathrm{NO}_{2}$-dependent $\mathrm{NO}$ production in plant roots decreases fermentative ethanol production during hypoxia (Oliveira et al., 2012; Oliveira et al., 2013).

Although NO has been well established as a signaling molecule, its high concentration in cells leads to cell death (Boscá and Hortelano, 1999; Brown and Borutaite, 2002). Therefore, it is critical to regulate its concentration in cells, as a higher amount of NO is formed under hypoxic and anoxic conditions. Two mechanisms are reported to occur in the

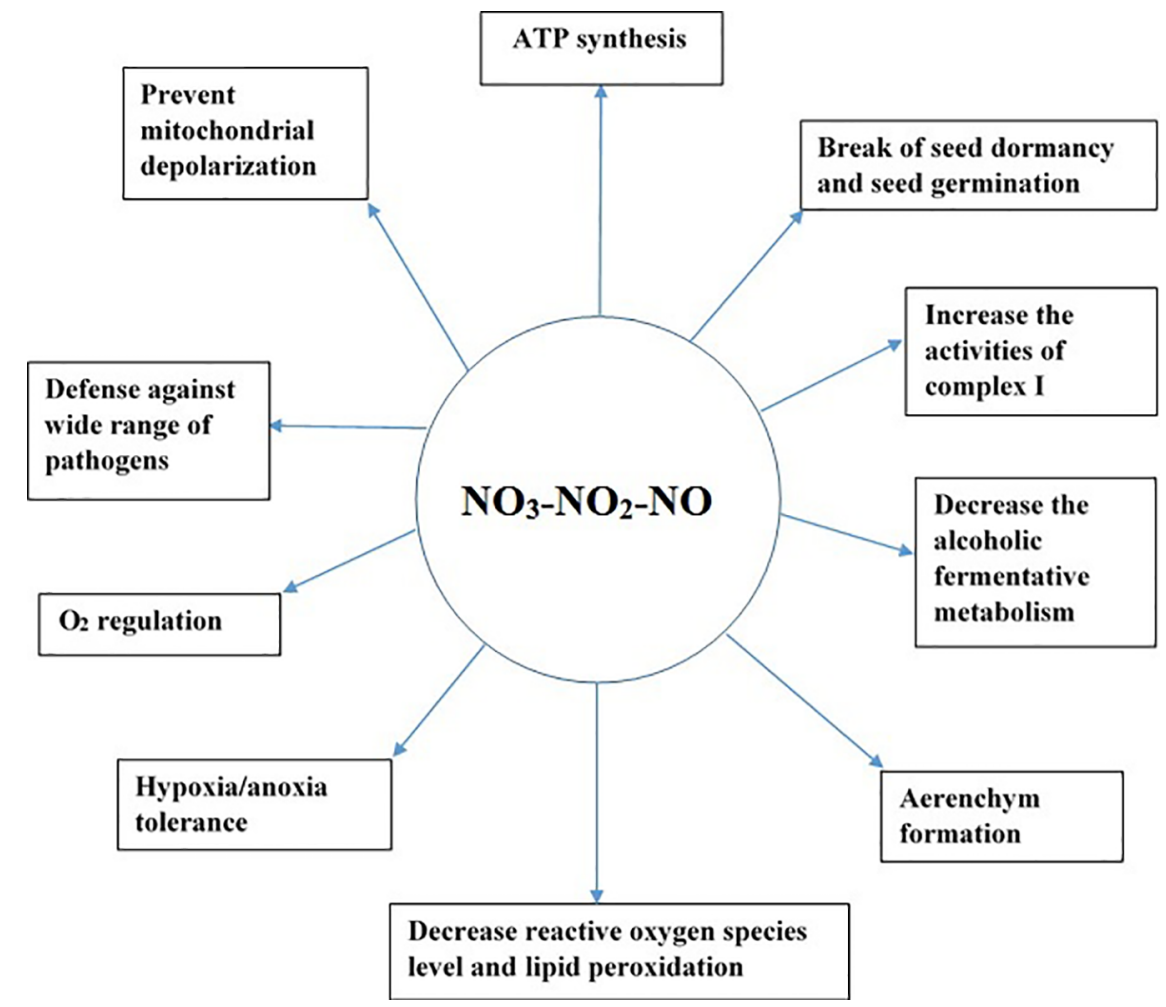

FIGURE 2 | Significance of the $\mathrm{NO}_{3}-\mathrm{NO}_{2}-\mathrm{NO}$ pathway in plants under hypoxic and anoxic conditions. 
mitochondria to detoxify the high amount of NO formed, namely, oxidation of $\mathrm{NO}$ to $\mathrm{NO}_{2}$ during normoxia (Cooper, 2002; Taylor and Moncada, 2010) and reduction of $\mathrm{NO}$ to $\mathrm{N}_{2} \mathrm{O}$ during hypoxia (Cooper, 2002). As both products of $\mathrm{NO}$ metabolism in the mitochondria, that is, $\mathrm{NO}_{2}$ and $\mathrm{N}_{2} \mathrm{O}$, are non-toxic, their formation might play a protective role in the mitochondria. If hypoxia-induced NO production in cells is high, it can cause DNA fragmentation, leading to cell death; however, if NO is scavenged, it can reduce DNA fragmentation (Wany et al., 2017). Therefore, scavenging of NO is essential to protect cells from high NO toxicity. Phytoglobins are reported to scavenge NO in the cytosol (Igamberdiev et al., 2010). Additionally, purified mitochondria have been reported to scavenge exogenous NO (Gupta et al., 2005; de Oliveira et al., 2008; Wulff et al., 2009; Gupta and Kaiser, 2010). Furthermore, the addition of NADH as an electron donor increased NO scavenging by the mitochondria (Gupta et al., 2005; de Oliveira et al., 2008; Wulff et al., 2009; Gupta et al., 2016), indicating that the mitochondria have a protective mechanism to detoxify the excess $\mathrm{NO}$ formed. NADH might act as an electron donor to reduce cytochrome c oxidase, leading to an increase in NO scavenging in purified mitochondria. As discussed in our proposed pathway of $\mathrm{N}_{2} \mathrm{O}$ formation in the mitochondria, the conversion of $\mathrm{NO}$ to $\mathrm{N}_{2} \mathrm{O}$ by the reduced form of $\mathrm{CcO}$ might be the potential pathway regulating excessive $\mathrm{NO}$ formed under oxygen-limited conditions in the mitochondria. Mitochondria are not only a source of NO, but also an important sink and target of NO (Igamberdiev et al., 2014), and long-term exposure of mitochondria to $\mathrm{NO}$ can lead to the dysfunction of mitochondria (Brown and Borutaite, 2002). Although the $\mathrm{NO}_{3}-\mathrm{NO}_{2}-\mathrm{NO}$ pathway has several roles (Figure 2) in plants during hypoxia and anoxia, $\mathrm{NO}$ accumulation at higher level is toxic to cells (Brown and Borutaite, 2002). Therefore, $\mathrm{N}_{2} \mathrm{O}$ formation in the mitochondria via the $\mathrm{NO}_{3}-\mathrm{NO}_{2}-\mathrm{NO}$ pathway might be a strategy to protect cells and mitochondrial components from excessive NO formed under oxygen-limited conditions. Therefore, at molecular level, further research should focus on measuring $\mathrm{NO}$ and $\mathrm{N}_{2} \mathrm{O}$ from isolated mitochondria to obtain more insights on mitochondria's role in scavenging excess $\mathrm{NO}$ during hypoxia and anoxia.

\section{DO PLANT CELLS REDUCE $\mathrm{N}_{2} \mathrm{O}$ TO $\mathrm{N}_{2}$ ?}

The last two enzymes of the denitrification process, namely, nitric oxide reductase (NOR) and nitrous oxide reductase $\left(\mathrm{N}_{2} \mathrm{OR}\right)$, merged to form $\mathrm{CcO}$ (Saraste and Castresana, 1994; Stanton et al., 2018). Moreover, the copper site in bacterial $\mathrm{N}_{2} \mathrm{OR}$ is similar to the $\mathrm{CuA}$ site in $\mathrm{CcO}$ (Kroneck, 2018). Many catalytic properties of $\mathrm{CcO}$ from denitrifying bacteria (Paracoccus denitrificans) and eukaryotic organisms are similar (Ludwig, 1987; Kadenbach et al., 1991). As eukaryotic mitochondrion is considered to be evolved from $P$. denitrificans, a denitrifying bacterium (John and Whatley, 1975), it may still possess rudimentary denitrification properties. Although during the evolution most of genes of the bacterium transferred to the nucleus, few remained in the mitochondrial DNA including genes of $\mathrm{CcO}$ (Kadenbach et al., 1991). Therefore, it may be possible that $\mathrm{CcO}$ of higher organisms might also possess similar properties like that of its ancestor, $P$. denitrificans. The significant negative relationship between $\mathrm{N}_{2} \mathrm{O}$ consumption and $\mathrm{CO}_{2}$ respiration rates in plants and lichens (Machacova et al., 2017) suggests that mitochondria are the possible site of $\mathrm{N}_{2} \mathrm{O}$ consumption. This $\mathrm{N}_{2} \mathrm{O}$ consumption observed in these eukaryotes might be at the site of $\mathrm{CcO}$, as this enzyme is formed from the last two enzymes of denitrification. There are also reports of emission of ${ }^{15} \mathrm{~N}$-labeled $\mathrm{N}_{2}$ from wheat crops supplied with ${ }^{15} \mathrm{~N}$-labeled $\mathrm{NO}_{2}$ (Vanecko and Varner, 1955), suggesting that under certain cell conditions, mitochondria may also metabolise $\mathrm{N}_{2} \mathrm{O}$ to $\mathrm{N}_{2}$. However, to date, $\mathrm{N}_{2}$ emission from plants is less reported. It may be due to the advanced systems of $\mathrm{O}_{2}$ regulation in plants, and this might inhibit the complete process of denitrification. A recent study, which measured $\mathrm{N}_{2} \mathrm{O}$ and $\mathrm{N}_{2}$ emission from soil-plant systems, showed that $\mathrm{N}_{2} \mathrm{O}$ and $\mathrm{N}_{2}$ emitted by $\mathrm{NO}_{3}$-rich soil-plant systems was three times higher than that by $\mathrm{NH}_{4}$-supplemented soil-plant systems and bare soil (Senbayram et al., 2020), and this suggests that the possible role of $\mathrm{N}_{2} \mathrm{O}$ and $\mathrm{N}_{2}$ production in plants. Further experiments at the molecular level (mitochondria) are needed to explore the reason for the significant negative relation between $\mathrm{N}_{2} \mathrm{O}$ emission and respiration rate in plants and lichen, as reported by Machacova et al. (2017).

\section{CONCLUSIONS}

To cope with the problems of global warming and ozone layer depletion, a good understanding of $\mathrm{N}_{2} \mathrm{O}$ formation processes in various source is critical. Therefore, the $\mathrm{N}_{2} \mathrm{O}$ formation process in plants is a matter of concern. The reductive pathway of NO formation in the mitochondria along with further reduction of $\mathrm{NO}$ by ETC is a possible pathway of $\mathrm{N}_{2} \mathrm{O}$ formation in plants. Considering available evidence, we conclude that there is strong possibility that plant cells produce $\mathrm{N}_{2} \mathrm{O}$ in the mitochondria under hypoxic and anoxic conditions. The theory that plants are only a conduit for $\mathrm{N}_{2} \mathrm{O}$ produced by soil-inhabiting microorganisms might be an ambiguous explanation. The root zone may sense hypoxia and anoxia due to the soil environmental conditions, which may favour $\mathrm{N}_{2} \mathrm{O}$ formation in the root mitochondria. As some studies have shown that $\mathrm{N}_{2} \mathrm{O}$ emission from tree stems is higher than that from soils in natural habitats (Welch et al., 2019), the proposed pathway of $\mathrm{N}_{2} \mathrm{O}$ formation in plants might play a significant role in understanding $\mathrm{N}$ cycling in eukaryotic organisms and the global $\mathrm{N}_{2} \mathrm{O}$ budget. Furthermore, we have highlighted the reduction of $\mathrm{NO}$ to $\mathrm{N}_{2} \mathrm{O}$ in the mitochondria, and therefore, it would be valuable to reassess the role of mitochondrial ETC under both hypoxic and anoxic conditions. Although, $\mathrm{N}_{2} \mathrm{O}$ is a potent greenhouse gas ,its formation in the mitochondria might help to protect the integrity of the mitochondria and protect cells from the toxicity of $\mathrm{NO}$ accumulation during hypoxia. 


\section{AUTHOR CONTRIBUTIONS}

AT wrote the manuscript. $\mathrm{CH}$ supervised the whole work. $\mathrm{CZ}, \mathrm{BP}, \mathrm{FB}$, and $\mathrm{WD}$ commented on the manuscript. All authors contributed to the article and approved the submitted version.

\section{FUNDING}

This work was funded by the National Natural Science Foundation of China (no. 41530859) and the National Key Research and

\section{REFERENCES}

Alber, N. A., Sivanesan, H., and Vanlerberghe, G. C. (2017). The occurrence and control of nitric oxide generation by the plant mitochondrial electron transport chain. Plant Cell Environ. 40, 1074-1085. doi: 10.1111/pce.12884

Alegria, A. E., Sanchez, S., and Quintana, I. (2004). Quinone-enhanced ascorbate reduction of nitric oxide: role of quinone redox potential. Free Radical Res. 38, 1107-1112. doi: 10.1080/10715760400009852

Allègre, A., Silvestre, J., Morard, P., Kallerhoff, J., and Pinelli, E. (2004). Nitrate reductase regulation in tomato roots by exogenous nitrate: a possible role in tolerance to long-term root anoxia. J. Exp. Bot. 55, 2625-2634. doi: 10.1093/ jxb/erh258

Ascenzi, P., Marino, M., Polticelli, F., Santucci, R., and Coletta, M. (2014). Cardiolipin modulates allosterically the nitrite reductase activity of horse heart cytochrome $\mathrm{c}$. J. Biol. Inorg. Chem. 19, 1195-1201. doi: 10.1007/s00775-014-1175-9

Astier, J., Gross, I., and Durner, J. (2018). Nitric oxide production in plants: an update. J. Exp. Bot. 69, 3401-3411. doi: 10.1093/jxb/erx420

Baggs, E. M. (2011). Soil microbial sources of nitrous oxide: recent advances in knowledge, emerging challenges and future direction. Curr. Opin. Env. Sust. 3, 321-327. doi: 10.1016/j.cosust.2011.08.011

Basu, S., Azarova, N. A., Font, M. D., King, S. B., Hogg, N., Gladwin, M. T., et al. (2008). Nitrite reductase activity of cytochrome c. J. Biol. Inorg. Chem. 283, 32590-32597. doi: 10.1074/jbc.M806934200

Beligni, M. V., and Lamattina, L. (2000). Nitric oxide stimulates seed germination and de-etiolation, and inhibits hypocotyl elongation, three light-inducible responses in plants. Planta 210 (2), 215-221. doi: 10.1007/PL00008128

Benamar, A., Rolletschek, H., Borisjuk, L., Avelange-Macherel, M. H., Curien, G., Mostefai, H. A., et al. (2008). Nitrite-nitric oxide control of mitochondrial respiration at the frontier of anoxia. BBA-Bioenergetics 1777, 1268-1275. doi: 10.1016/j.bbabio.2008.06.002

Bender, D., and Schwarz, G. (2018). Nitrite-dependent nitric oxide synthesis by molybdenum enzymes. FEBS Lett. 592, 2126-2139. doi: 10.1002/1873-3468.13089

Bethke, P. C., Gubler, F., Jacobsen, J. V., and Jones, R. L. (2004). Dormancy of Arabidopsis seeds and barley grains can be broken by nitric oxide. Planta 219, 847-855. doi: 10.1007/s00425-004-1282-x

Blomberg, M. R., and Ädelroth, P. (2018). Mechanisms for enzymatic reduction of nitric oxide to nitrous oxide-A comparison between nitric oxide reductase and cytochrome c oxidase. BBA-Bioenergetics 1859, 1223-1234. doi: 10.1016/ j.bbabio. 2018.09 .368

Boscá, L., and Hortelano, S. (1999). Mechanisms of nitric oxide-dependent apoptosis: involvement of mitochondrial mediators. Cell Signal. 11, 239-244. doi: 10.1016/S0898-6568(98)00064-3

Botrel, A., and Kaiser, W. M. (1997). Nitrate reductase activation state in barley roots in relation to the energy and carbohydrate status. Planta 201, 496-501. doi: 10.1007/s004250050094

Bowatte, S., Newton, P. C., Theobald, P., Brock, S., Hunt, C., Lieffering, M., et al. (2014). Emissions of nitrous oxide from the leaves of grasses. Plant Soil 374, 275-283. doi: 10.1007/s11104-013-1879-6

Brown, G. C., and Borutaite, V. (2002). Nitric oxide inhibition of mitochondrial respiration and its role in cell death. Free Radical Bio. Med. 33, 1440-1450. doi: 10.1016/S0891-5849(02)01112-7
Development Program of China (2016YFD0800102-4 and 2018YFC0213300-01).

\section{ACKNOWLEDGMENTS}

AT is grateful to CAS-TWAS President's Fellowship Program for granting the Ph.D. fellowship. We are thankful to Prof. Chengcai Chu from the Institute of Genetics and Developmental Biology, Beijing, China, for thoughtful comments. Moreover, we are grateful to Prof. Oene Oenema and Prof. Jiafa Luo for their valuable comments.

Brudvig, G. W., Stevens, T. H., and Chan, S. II. (1980). Reactions of nitric oxide with cytochrome c oxidase. Biochemistry 19, 5275-5285. doi: 10.1021/ bi00564a020

Calatrava, V., Chamizo-Ampudia, A., Sanz-Luque, E., Ocaña-Calahorro, F., Llamas, A., Fernandez, E., et al. (2017). How Chlamydomonas handles nitrate and the nitric oxide cycle. J. Exp. Bot. 68, 2593-2602. doi: 10.1093/ jxb/erw507

Castello, P. R., David, P. S., McClure, T., Crook, Z., and Poyton, R. O. (2006). Mitochondrial cytochrome oxidase produces nitric oxide under hypoxic conditions: implications for oxygen sensing and hypoxic signaling in eukaryotes. Cell Metab. 3, 277-287. doi: 10.1016/j.cmet.2006.02.011

Chamizo-Ampudia, A., Sanz-Luque, E., Llamas, A., Galvan, A., and Fernandez, E. (2017). Nitrate reductase regulates plant nitric oxide homeostasis. Trends Plant Sci. 22, 163-174. doi: 10.1016/j.tplants.2016.12.001

Chang, C., Janzen, H. H., Nakonechny, E. M., and Cho, C. M. (1998). Nitrous oxide emission through plants. Soil Sci. Soc Am. J. 62, 35-38. doi: 10.2136/ sssaj1998.03615995006200010005x

Collman, J. P., Devaraj, N. K., Decréau, R. A., Yang, Y., Yan, Y. L., Ebina, W., et al. (2007). A cytochrome $c$ oxidase model catalyzes oxygen to water reduction under rate-limiting electron flux. Science 315, 1565-1568. doi: 10.1126/ science. 1135844

Cooper, C. E. (2002). Nitric oxide and cytochrome oxidase: substrate, inhibitor or effector? Trends Biochem. Sci. 27, 33-39. doi: 10.1016/S0968-0004(01)02035-7

Davidson, E. A., and Kanter, D. (2014). Inventories and scenarios of nitrous oxide emissions. Environ. Res. Lett. 9:105012. doi: 10.1088/1748-9326/9/10/105012

de Oliveira, H. C., Wulff, A., Saviani, E. E., and Salgado, I. (2008). Nitric oxide degradation by potato tuber mitochondria: evidence for the involvement of external $\mathrm{NAD}(\mathrm{P}) \mathrm{H}$ dehydrogenases. BBA-Bioenergetics 1777, 470-476. doi: 10.1016/j.bbabio.2008.02.006

Dean, J. V., and Harper, J. E. (1986). Nitric oxide and nitrous oxide production by soybean and winged bean during the in vivo nitrate reductase assay. Plant Physiol. 82, 718-723. doi: 10.1104/pp.82.3.718

Fan, X., Jia, L., Li, Y., Smith, S. J., Miller, A. J., and Shen, Q. (2007). Comparing nitrate storage and remobilization in two rice cultivars that differ in their nitrogen use efficiency. J. Exp. Bot. 58 (7), 1729-1740. doi: 10.1093/jxb/erm033

Gao, G. F., Li, P. F., Zhong, J. X., Shen, Z. J., Chen, J., Li, Y. T., et al. (2019). Spartina alterniflora invasion alters soil bacterial communities and enhances soil $\mathrm{N}_{2} \mathrm{O}$ emissions by stimulating soil denitrification in mangrove wetland. Sci. Total Environ. 653, 231-240. doi: 10.1016/j.scitotenv.2018.10.277

Ghafourifar, P., and Cadenas, E. (2005). Mitochondrial nitric oxide synthase. Trends Pharmacol. Sci. 26, 190-195. doi: 10.1016/j.tips.2005.02.005

Ghafourifar, P., and Richter, C. (1997). Nitric oxide synthase activity in mitochondria. FEBS Lett. 418, 291-296. doi: 10.1016/S0014-5793(97)01397-5

Giulivi, C., Poderoso, J. J., and Boveris, A. (1998). Production of nitric oxide by mitochondria. J. Biol. Chem. 273, 11038-11043. doi: 10.1074/jbc.273.18.11038

Goshima, N., Mukai, T., Suemori, M., Takahashi, M., Caboche, M., and Morikawa, H. (1999). Emission of nitrous oxide $\left(\mathrm{N}_{2} \mathrm{O}\right)$ from transgenic tobacco expressing antisense NiR mRNA. Plant J. 19, 75-80. doi: 10.1046/j.1365-313X.1999. 00494.x

Guieysse, B., Plouviez, M., Coilhac, M., and Cazali, L. (2013). Nitrous Oxide $\left(\mathrm{N}_{2} \mathrm{O}\right)$ production in axenic Chlorella vulgaris microalgae cultures: evidence, putative 
pathways, and potential environmental impacts. Biogeosciences 10, 6737-6746. doi: 10.5194/bg-10-6737-2013

Guo, F. Q., and Crawford, N. M. (2005). Arabidopsis nitric oxide synthase1 is targeted to mitochondria and protects against oxidative damage and darkinduced senescence. Plant Cell 17, 3436-3450. doi: 10.1105/tpc.105.037770

Gupta, K. J., and Igamberdiev, A. U. (2011). The anoxic plant mitochondrion as a nitrite: NO reductase. Mitochondrion 11, 537-543. doi: 10.1016/j.mito.2011. 03.005

Gupta, K. J., and Kaiser, W. M. (2010). Production and scavenging of nitric oxide by barley root mitochondria. Plant Cell Physiol. 51, 576-584. doi: 10.1093/pcp/ pcq022

Gupta, K. J., Stoimenova, M., and Kaiser, W. M. (2005). In higher plants, only root mitochondria, but not leaf mitochondria reduce nitrite to $\mathrm{NO}$, in vitro and in situ. J. Exp. Bot. 56, 2601-2609. doi: 10.1093/jxb/eri252

Gupta, K. J., Fernie, A. R., Kaiser, W. M., and van Dongen, J. T. (2011). On the origins of nitric oxide. Trends Plant Sci. 16, 160-168. doi: 10.1016/j.tplants. 2010.11.007

Gupta, A. K., Kumari, A., Mishra, S., Wany, A., and Gupta, K. J. (2016). "The functional role of nitric oxide in plant mitochondrial metabolism," in Advances in Botanical Research, vol. 77. (Cambridge, MA: Academic Press), 145-163. doi: 10.1016/bs.abr.2015.10.007

Hachiya, T., and Sakakibara, H. (2017). Interactions between nitrate and ammonium in their uptake, allocation, assimilation, and signaling in plants. J. Exp. Bot. 68, 2501-2512. doi: 10.1093/jxb/erw449

Hakata, M., Takahashi, M., Zumft, W., Sakamoto, A., and Morikawa, H. (2003). Conversion of the nitrate nitrogen and nitrogen dioxide to nitrous oxides in plants. Acta Biotechnol. 23, 249-257. doi: 10.1002/abio.200390032

Horchani, F., Aschi-Smiti, S., and Brouquisse, R. (2010). Involvement of nitrate reduction in the tolerance of tomato (Solanum lycopersicum L.) plants to prolonged root hypoxia. Acta Physiol. Plant 32, 1113-1123. doi: 10.1007/ s11738-010-0503-0

Horchani, F., Prévot, M., Boscari, A., Evangelisti, E., Meilhoc, E., Bruand, C., et al. (2011). Both plant and bacterial nitrate reductases contribute to nitric oxide production in Medicago truncatula nitrogen-fixing nodules. Plant Physiol. 155, 1023-1036. doi: 10.1104/pp.110.166140

Horn, M. A., Schramm, A., and Drake, H. L. (2003). The earthworm gut: an ideal habitat for ingested $\mathrm{N}_{2} \mathrm{O}$-producing microorganisms. Appl. Environ. Microb. 69, 1662-1669. doi: 10.1128/AEM.69.3.1662-1669.2003

Hu, H. W., Chen, D., and He, J. Z. (2015). Microbial regulation of terrestrial nitrous oxide formation: understanding the biological pathways for prediction of emission rates. FEMS Microbiol. Rev. 39, 729-749. doi: 10.1093/femsre/ fuv021

Igamberdiev, A. U., and Hill, R. D. (2009). Plant mitochondrial function during anaerobiosis. Ann. Bot. 103, 259-268. doi: 10.1093/aob/mcn100

Igamberdiev, A. U., Bykova, N. V., Shah, J. K., and Hill, R. D. (2010). Anoxic nitric oxide cycling in plants: participating reactions and possible mechanisms. Physiol. Plantarum 138, 393-404. doi: 10.1111/j.1399-3054.2009.01314.x

Igamberdiev, A. U., Ratcliffe, R. G., and Gupta, K. J. (2014). Plant mitochondria: source and target for nitric oxide. Mitochondrion 19, 329-333. doi: 10.1016/ j.mito.2014.02.003

Jakobs, H. H., Froriep, D., Havemeyer, A., Mendel, R. R., Bittner, F., and Clement, B. (2014). The mitochondrial amidoxime reducing component (mARC): involvement in metabolic reduction of $\mathrm{N}$-oxides, oximes and $\mathrm{N}$ hydroxyamidinohydrazones. ChemMedChem 9, 2381-2387. doi: 10.1002/ cmdc.201402127

Jansson, E.Å., Huang, L., Malkey, R., Govoni, M., Nihlén, C., Olsson, A., et al (2008). A mammalian functional nitrate reductase that regulates nitrite and nitric oxide homeostasis. Nat. Chem. Biol. 4, 411. doi: 10.1038/nchembio.92

John, P., and Whatley, F. R. (1975). Paracoccus denitrificans and the evolutionary origin of the mitochondrion. Nature 254, 495. doi: 10.1038/254495a0

Johnson, K. S., and Barbehenn, R. V. (2000). Oxygen levels in the gut lumens of herbivorous insects. J. Insect Physiol. 46, 897-903. doi: 10.1016/S0022-1910(99) 00196-1

Kadenbach, B., Stroh, A., Hüther, F. J., Reimann, A., and Steverding, D. (1991). Evolutionary aspects of cytochromec oxidase. J. Bioenerg. Biomembr. 23 (2), 321-334. doi: 10.1007/BF00762225

Klepper, L. A. (1987). Nitric oxide emissions from soybean leaves during in vivo nitrate reductase assays. Plant Physiol. 85, 96-99. doi: 10.1104/pp.85.1.96
Kobayashi, M., Matsuo, Y., Takimoto, A., Suzuki, S., Maruo, F., and Shoun, H. (1996). Denitrification, a novel type of respiratory metabolism in fungal mitochondrion. J. Biol. Chem. 271, 16263-16267. doi: 10.1074/jbc.271.27.1626

Koivisto, A., Matthias, A., Bronnikov, G., and Nedergaard, J. (1997). Kinetics of the inhibition of mitochondrial respiration by NO. FEBS Lett. 417, 75-80. doi: 10.1016/S0014-5793(97)01258-1

Kozlov, A. V., Staniek, K., and Nohl, H. (1999). Nitrite reductase activity is a novel function of mammalian mitochondria. FEBS Lett. 454, 127-130. doi: 10.1016/ S0014-5793(99)00788-7

Kroneck, P. M. (2018). Walking the seven lines: binuclear copper A in cytochrome c oxidase and nitrous oxide reductase. J. Biol. Inorg. Chem. 23, 27-39. doi: 10.1007/s00775-017-1510-z

Lenhart, K., Weber, B., Elbert, W., Steinkamp, J., Clough, T., Crutzen, P., et al. (2015). Nitrous oxide and methane emissions from cryptogamic covers. Global Change Biol. 21, 3889-3900. doi: 10.1111/gcb.12995

Lenhart, K., Behrendt, T., Greiner, S., Steinkamp, J., Well, R., Giesemann, A., et al. (2019). Nitrous oxide effluxes from plants as a potentially important source to the atmosphere. New Phytol. 221, 1398-1408. doi: 10.1111/nph.15455

Ludwig, B. (1987). Cytochrome c oxidase in prokaryotes. FEMS Microbiol. Rev. 3 (1), 41-56. doi: 10.1111/j.1574-6968.1987.tb02451.x

Lundberg, J. O., Weitzberg, E., and Gladwin, M. T. (2008). The nitrate-nitritenitric oxide pathway in physiology and therapeutics. Nat. Rev. Drug Discovery 7, 156. doi: $10.1038 / \mathrm{nrd} 2466$

Maathuis, F. J. (2009). Physiological functions of mineral macronutrients. Curr. Opin. Plant Biol. 12, 250-258. doi: 10.1016/j.pbi.2009.04.003

Machacova, K., Papen, H., Kreuzwieser, J., and Rennenberg, H. (2013). Inundation strongly stimulates nitrous oxide emissions from stems of the upland tree Fagus sylvatica and the riparian tree Alnus glutinosa. Plant Soil 364, 287-301. doi: 10.1007/s11104-012-1359-4

Machacova, K., Maier, M., Svobodova, K., Lang, F., and Urban, O. (2017). Cryptogamic stem covers may contribute to nitrous oxide consumption by mature beech trees. Sci. Rep. 7, 13243. doi: 10.1038/s41598-017-13781-7

Maia, L. B., and Moura, J. J. (2015). Nitrite reduction by molybdoenzymes: a new class of nitric oxide-forming nitrite reductases. J. Biol. Inorg. Chem. 20, 403433. doi: 10.1007/s00775-014-1234-2

Miller, A. J., and Cramer, M. D. (2005). "Root nitrogen acquisition and assimilation," in Root Physiology: from Gene to Function. (Dordrecht: Springer), 1-36.

Morard, P., Silvestre, J., Lacoste, L., Caumes, E., and Lamaze, T. (2004). Nitrate uptake and nitrite release by tomato roots in response to anoxia. J. Plant Physiol. 161, 855-865. doi: 10.1016/j.jplph.2003.11.003

Moreau, M., Lee, G.II, Wang, Y., Crane, B. R., and Klessig, D. F. (2008). AtNOS/ AtNOA1 is a functional Arabidopsis thaliana cGTPase and not a nitric-oxide synthase. J. Biol. Chem. 283, 32957-32967. doi: 10.1074/jbc.M804838200

Oliveira, H. C., and Sodek, L. (2013). Effect of oxygen deficiency on nitrogen assimilation and amino acid metabolism of soybean root segments. Amino Acids 44, 743-755. doi: 10.1007/s00726-012-1399-3

Oliveira, H. C., Salgado, I., and Sodek, L. (2012). Involvement of nitrite in the nitrate-mediated modulation of fermentative metabolism and nitric oxide production of soybean roots during hypoxia. Planta 237, 255-264. doi: 10.1007/s00425-012-1773-0

Oliveira, H. C., Salgado, I., and Sodek, L. (2013). Nitrite decreases ethanol production by intact soybean roots submitted to oxygen deficiency: a role for mitochondrial nitric oxide synthesis? Plant Signal. Behav. 8, e23578. doi: $10.4161 /$ psb.23578

O’Brien, J. A., Vega, A., Bouguyon, E., Krouk, G., Gojon, A., Coruzzi, G., et al. (2016). Nitrate transport, sensing, and responses in plants. Mol. Plant 9, 837856. doi: 10.1016/j.molp.2016.05.004

Pearce, L. L., Kanai, A. J., Birder, L. A., Pitt, B. R., and Peterson, J. (2002). The catabolic fate of nitric oxide the nitric oxide oxidase and peroxynitrite reductase activities of cytochrome oxidase. J. Biol. Chem. 277, 13556-13562. doi: $10.1074 /$ jbc.M109838200

Planchet, E., Gupta, K. J., Sonoda, M., and Kaiser, W. M. (2005). Nitric oxide emission from tobacco leaves and cell suspensions: rate limiting factors and evidence for the involvement of mitochondrial electron transport. Plant J. 41, 732-743. doi: 10.1111/j.1365-313X.2005.02335.x

Plouviez, M., Wheeler, D., Shilton, A., Packer, M. A., McLenachan, P. A., SanzLuque, E., et al. (2017). The biosynthesis of nitrous oxide in the green alga Chlamydomonas reinhardtii. Plant J. 91, 45-56. doi: 10.1111/tpj.13544 
Plouviez, M., Shilton, A., Packer, M. A., and Guieysse, B. (2019). Nitrous oxide emissions from microalgae: potential pathways and significance. J. Appl. Phycol. 31, 1-8. doi: 10.1007/s10811-018-1531-1

Poderoso, J. J., Helfenberger, K., and Poderoso, C. (2019). The effect of nitric oxide on mitochondrial respiration. Nitric. Oxide 88, 61-72. doi: 10.1016/j.niox. 2019.04.005

Rockel, P., Strube, F., Rockel, A., Wildt, J., and Kaiser, W. M. (2002). Regulation of nitric oxide (NO) production by plant nitrate reductase in vivo and in vitro. J. Exp. Bot. 53, 103-110. doi: 10.1093/jexbot/53.366.103

Röszer, T. (2012). The biology of subcellular nitric oxide. Dordrecht: Springer. doi: 10.1007/978-94-007-2819-6

Rusch, H., and Rennenberg, H. (1998). Black alder (Alnus glutinosa (L.) Gaertn.) trees mediate methane and nitrous oxide emission from the soil to the atmosphere. Plant Soil 201, 1-7. doi: 10.1023/A:1004331521059

Sanchez-Cruz, P., and Alegría, A. E. (2009). Quinone-enhanced reduction of nitric oxide by xanthine/xanthine oxidase. Chem. Res. Toxicol. 22, 818-823. doi: $10.1021 / \mathrm{tx} 800392 \mathrm{j}$

Saraste, M., and Castresana, J. (1994). Cytochrome oxidase evolved by tinkering with denitrification enzymes. FEBS Lett. 341, 1-4. doi: 10.1016/0014-5793(94) 80228-9

Saraste, M. (1994). Structure and evolution of cytochrome oxidase. Anton. Leeuw. Int. J. 65, 285-287. doi: 10.1007/BF00872214

Senbayram, M., Well, R., Shan, J., Bol, R., Burkart, S., Jones, D. L., et al. (2020). Rhizosphere processes in nitrate-rich barley soil tripled both $\mathrm{N}_{2} \mathrm{O}$ and $\mathrm{N}_{2}$ losses due to enhanced bacterial and fungal denitrification. Plant Soil 448, 509522. doi: 10.1007/s11104-020-04457-9

Smart, D. R., and Bloom, A. J. (2001). Wheat leaves emit nitrous oxide during nitrate assimilation. P. Natl. Acad. Sci. 98, 7875-7878. doi: 10.1073/pnas.131572798

Sparacino-Watkins, C. E., Tejero, J., Sun, B., Gauthier, M. C., Thomas, J., Ragireddy, V., et al. (2014). Nitrite reductase and nitric-oxide synthase activity of the mitochondrial molybdopterin enzymes mARC1 and mARC2. J. Biol. Chem. 289, 10345-10358. doi: 10.1074/jbc.M114.555177

Stanton, C. L., Reinhard, C. T., Kasting, J. F., Ostrom, N. E., Haslun, J. A., Lyons, T. W., et al. (2018). Nitrous oxide from chemodenitrification: A possible missing link in the Proterozoic greenhouse and the evolution of aerobic respiration. Geobiology 16, 597-609. doi: 10.1111/gbi.12311

Stief, P., Poulsen, M., Nielsen, L. P., Brix, H., and Schramm, A. (2009). Nitrous oxide emission by aquatic macrofauna. P. Natl. Acad. Sci. 106, 4296-4300. doi: 10.1073/pnas.0808228106

Stoimenova, M., Igamberdiev, A. U., Gupta, K. J., and Hill, R. D. (2007). Nitritedriven anaerobic ATP synthesis in barley and rice root mitochondria. Planta 226, 465-474. doi: 10.1007/s00425-007-0496-0

Sugiura, M., Georgescu, M. N., and Takahashi, M. (2007). A nitrite transporter associated with nitrite uptake by higher plant chloroplasts. Plant Cell Physiol. 48, 1022-1035. doi: 10.1093/pcp/pcm073

Syakila, A., and Kroeze, C. (2011). The global nitrous oxide budget revisited. GGMM 1, 17-26. doi: 10.3763/ghgmm.2010.0007

Taylor, C. T., and Moncada, S. (2010). Nitric oxide, cytochrome C oxidase, and the cellular response to hypoxia. Arterioscl. Throm. Vas. 30, 643-647. doi: 10.1161/ ATVBAHA.108.181628

Thomson, A. J., Giannopoulos, G., Pretty, J., Baggs, E. M., and Richardson, D. J. (2012). Biological sources and sinks of nitrous oxide and strategies to mitigate emissions. Philos. T. R. Soc B. 367, 1157-1168. doi: 10.1098/rstb.2011.0415

Tian, H., Yang, J., Lu, C., Xu, R., Canadell, J. G., Jackson, R. B., et al. (2018). The global $\mathrm{N}_{2} \mathrm{O}$ model intercomparison project. B. Am. Meteorol. Soc. 99, 12311251. doi: 10.1175/BAMS-D-17-0212.1

Tischner, R., Planchet, E., and Kaiser, W. M. (2004). Mitochondrial electron transport as a source for nitric oxide in the unicellular green alga Chlorella sorokiniana. FEBS Lett. 576, 151-155. doi: 10.1016/j.febslet.2004.09.004

van der Leij, M., Smith, S., and Miller, A. (1998). Remobilisation of vacuolar stored nitrate in barley root cells. Planta 205, 64-72. doi: 10.1007/s004250050297
Vanecko, S., and Varner, J. E. (1955). Studies on nitrite metabolism in higher plants. Plant Physiol. 30:388. doi: 10.1104/pp.30.4.388

Vartapetian, B. B., Andreeva, I. N., Generozova, I. P., Polyakova, L.II, Maslova, I. P., Dolgikh, Y. II, et al. (2003). Functional electron microscopy in studies of plant response and adaptation to anaerobic stress. Ann. Bot. 91, 155-172. doi: 10.1093/ aob/mcf244

Voesenek, L. A., Sasidharan, R., Visser, E. J., and Bailey-Serres, J. (2016). Flooding stress signaling through perturbations in oxygen, ethylene, nitric oxide and light. New Phytol. 209, 39-43. doi: 10.1111/nph.13775

von Wirén, N., Gazzarrini, S., Gojon, A., and Frommer, W. B. (2000). The molecular physiology of ammonium uptake and retrieval. Curr. Opin. Plant Biol. 3, 254-261. doi: 10.1016/S1369-5266(00)80074-6

Wany, A., Kumari, A., and Gupta, K. J. (2017). Nitric oxide is essential for the development of aerenchyma in wheat roots under hypoxic stress. Plant Cell Environ. 40, 3002-3017. doi: 10.1111/pce.13061

Wany, A., Gupta, A. K., Kumari, A., Mishra, S., Singh, N., Pandey, S., et al. (2019). Nitrate nutrition influences multiple factors in order to increase energy efficiency under hypoxia in Arabidopsis. Ann. Bot. 123, 691-705. doi: $10.1093 / \mathrm{aob} / \mathrm{mcy} 202$

Ward, N. D., Indivero, J., Gunn, C., Wang, W., Bailey, V., and McDowell, N. G. (2019). Longitudinal gradients in tree stem greenhouse gas concentrations across six Pacific Northwest coastal forests. J. Geophys. Res.- Biogeo. 124, 14011412. doi: 10.1029/2019JG005064

Weathers, P. J., and Niedzielski, J. J. (1986). Nitrous oxide production by cyanobacteria. Arch. Microbiol. 146, 204-206. doi: 10.1007/BF00402352

Weathers, P. J. (1984). $\mathrm{N}_{2} \mathrm{O}$ evolution by green algae. Appl. Environ. Microb. 48, 1251-1253. doi: 10.1128/AEM.48.6.1251-1253.1984

Welch, B., Gauci, V., and Sayer, E. J. (2019). Tree stem bases are sources of $\mathrm{CH}_{4}$ and $\mathrm{N}_{2} \mathrm{O}$ in a tropical forest on upland soil during the dry to wet season transition. Global Change boil. 25, 361-372. doi: 10.1111/gcb.14498

Wen, Y., Corre, M. D., Rachow, C., Chen, L., and Veldkamp, E. (2017). Nitrous oxide emissions from stems of alder, beech and spruce in a temperate forest. Plant Soil 420, 423-434. doi: 10.1007/s11104-017-3416-5

Wendehenne, D., Pugin, A., Klessig, D. F., and Durner, J. (2001). Nitric oxide: comparative synthesis and signaling in animal and plant cells. Trends Plant Sci. 6, 177-183. doi: 10.1016/S1360-1385(01)01893-3

Woehle, C., Roy, A. S., Glock, N., Wein, T., Weissenbach, J., Rosenstiel, P., et al. (2018). A novel eukaryotic denitrification pathway in foraminifera. Curr. Biol. 28, 2536-2543. doi: 10.1016/j.cub.2018.06.027

Wulff, A., Oliveira, H. C., Saviani, E. E., and Salgado, I. (2009). Nitrite reduction and superoxide-dependent nitric oxide degradation by Arabidopsis mitochondria: influence of external NAD (P) $\mathrm{H}$ dehydrogenases and alternative oxidase in the control of nitric oxide levels. Nitric. Oxide 21, 132139. doi: 10.1016/j.niox.2009.06.003

Zhao, X. J., Sampath, V., and Caughey, W. S. (1995). Cytochrome c oxidase catalysis of the reduction of nitric oxide to nitrous oxide. Biochem. Bioph. Res. Co. 212, 1054-1060. doi: 10.1006/bbrc.1995.2076

Zhao, L., Liu, F., Crawford, N. M., and Wang, Y. (2018). Molecular regulation of nitrate responses in plants. Int. J. Mol. Sci. 19, 2039. doi: 10.3390/ijms19072039

Conflict of Interest: The authors declare that the research was conducted in the absence of any commercial or financial relationships that could be construed as a potential conflict of interest.

Copyright (c) 2020 Timilsina, Zhang, Pandey, Bizimana, Dong and Hu. This is an open-access article distributed under the terms of the Creative Commons Attribution License (CC BY). The use, distribution or reproduction in other forums is permitted, provided the original author(s) and the copyright owner(s) are credited and that the original publication in this journal is cited, in accordance with accepted academic practice. No use, distribution or reproduction is permitted which does not comply with these terms. 